\title{
Student Views on The Theme of "Historically Narrated Urban Furniture Workshop" And Its Technological Uses in Design Education
}

\author{
Şebnem Ertaş ${ }^{1 *}$, Funda Kurak Açici ${ }^{1}$, Makbulenur Bekar ${ }^{2}$ \\ ${ }^{1}$ Karadeniz Technical University, Department of Interior Architecture, Trabzon, TURKEY \\ ${ }^{2}$ Karadeniz Technical University, Department of Landscape Architecture, Trabzon, TURKEY \\ Received 21 September 2017 - Revised 23 October 2017 • Accepted 3 November 2017
}

\begin{abstract}
Design is a scientific process that incorporates several different disciplines and responds to the requirements of the natural environment with aesthetics and creativity. Short term "design studies" such as studio workshops, symposiums, workshops, student meetings, etc., where all disciplines including those based on design and creativity come together and various works are presented, are an important part of the education process. These include seminars, exhibitions, workshops and similar events that are held throughout the world, which are effective organizations in the design education process. In the present paper, the "History Narrated with Urban Furniture, Konya / Sille" workshop that was organized within the context of BAP 01 project no. SBA-2016-5350 at Karadeniz Technical University in 2016-2017 academic year was discussed. The study was based on the data collected during the workshop activities conducted with 20 students. The study aimed to measure of the use of technology by the achievements of students in informal design education studies that become prevalent in Turkey and worldwide and their interaction with formal education based on the collected data. The survey results were based on the percentages (\%) with respect to total values. Finally, recommendations for future design training events were made based on the survey data.
\end{abstract}

Keywords: design education, technologies, workshop

\section{INTRODUCTION}

In the twenty-first century, the age of knowledge and technology, the use of technology has increased in order to reach information in all areas of life. Technology is a combination of creativity and intelligence with science, art, engineering, economics and social work in order to improve the quality of human life. It is an attempt to make anything better, faster, easier, more economical and more efficient (Keçel, 2009). Today, almost all business sectors need individuals who can actively use technology to relay their knowledge (Barth et al 2012). In this context, there has been a compulsory change in educational institutions and the use of technology together with traditional methods has become a necessity. The discipline of architecture has also been influenced by this process and added courses with digital technologies to the existing course content. However, applications such as drawing on paper and making models, which are traditional design and expression tools in architectural education, are still in progress (Figure 1).

Digital technologies are used as auxiliary tools. This hybrid education system, which continues today, is seen as a transition process to digital technologies (Ylldırm, 2010). Because, two and three dimensional drawing expressions are the common language of design education. The use of this language is an effective analysis tool at every stage of the design process. Drawing is the tool of options and possibilities (Nerdinger, 2004). At the same time, this process depends on observation and assimilation in these studios (Kvan ve Yunyan, 2005). In the design 


\section{Contribution of this paper to the literature}

- This study includes use of computers in design process, and expression of traditional tools as the tools for visualization of design. For this reason, a hybrid training process with a combination of traditional and digital technologies can be experienced. And can be produced with less effort in digitalized methods.

- There are two important points that contributes to the existing literature. First is the discussion on student views and conclusions derived from the relationship between architectural education and technology, Secondly, the assessment of informal activities to formal activities realized in this study.

- The mental and students' visual thinking ability with the help of technology brings new perspectives to criticise life and improve the functionality of environment.
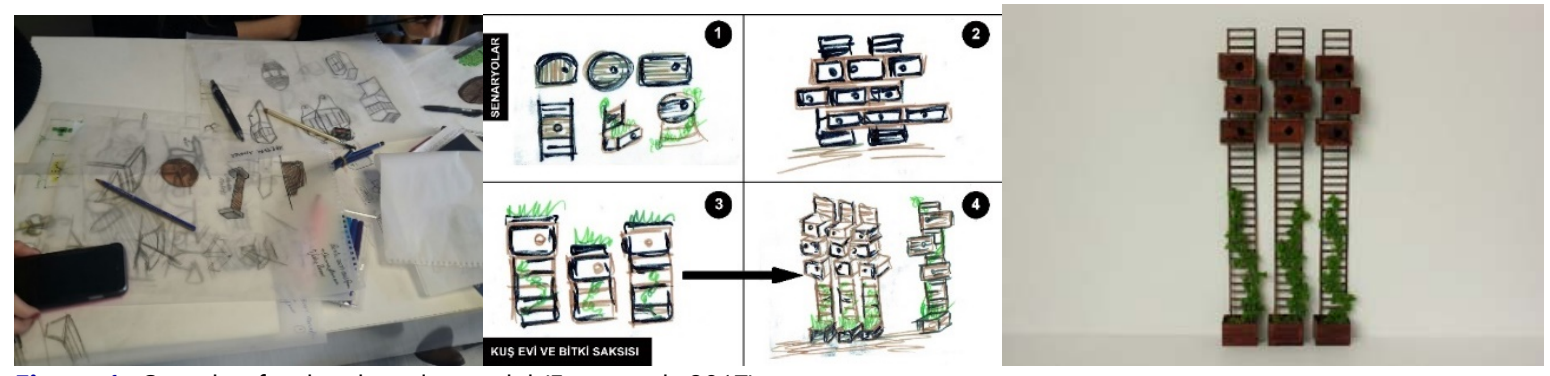

Figure 1. Sample of a sketch and a model (Ertas et al., 2017)

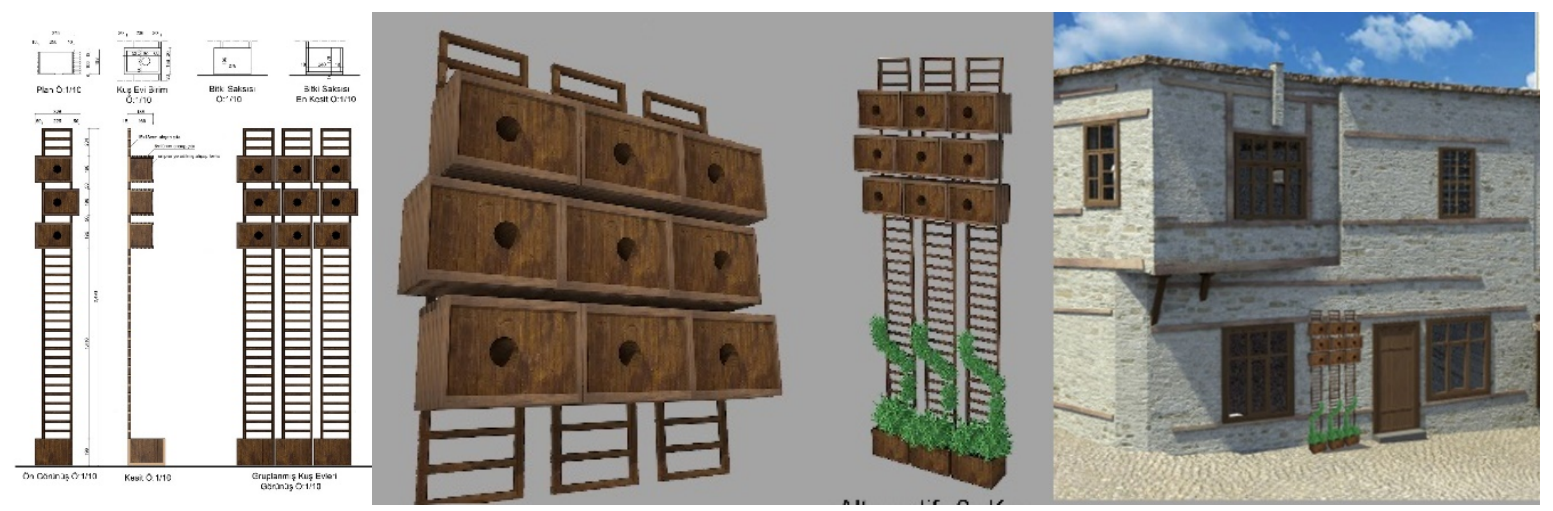

Figure 2. Two and three dimensional drawing samples (Ertas et al., 2017)

education effective use of software such as two-dimensional and three-dimensional programs, animations, graphics programs, etc., and access to information via the Internet, has enabled computer support (Figure 2).

It has become a requirement in many courses or activities in the process and contributed to different learning environments. These learning environments include educational workshops, studio workshops, symposiums, workshops, student meetings where design disciplines can be found together. Design activity is the result of the harmonious coexistence of art and science by its nature. Today, as technology is integrated into it, the identification of the main structure in design has become an important tool that enables the design activity to take shape. Design studios using two-dimensional drawing and three-dimensional modeling, animations, photorealistic simulations, electronic archives and librarianship services, remote access facilities on the internet became necessary (Yildırım, 2010). Because, visual analogy is a reasoning strategy that emerges as a trial- and-eror such as design (Casakin and Goldschmidt, 1999). For this reason, the contribution of the use of technology in both the formal and the informal studio training process has been a subject that needs to be questioned. Design studios are an opportunity to offer an essentially hands-on learning environment for students (Armstrong, 1999). Students gain direct experience of design experience in design education. This experience is carried out through workshops or competitions in informal education within the scope of the architectural project course in the studio during the formal education process. All education methods are becoming more dynamic with technology, reinforcing their knowledge (Ciravoğlu, 2001).

Within the scope of the study, during the "History Described with Urban Furniture Konya / Sille" activities, in 2016-2017 educational year, the use of technology in the workshop process, where the students from architecture, interior architecture and landscape architecture of Karadeniz Technical University attended, was evaluated according to student opinions. The workshop process and the formal training contribution of this process have also been examined in this context. 


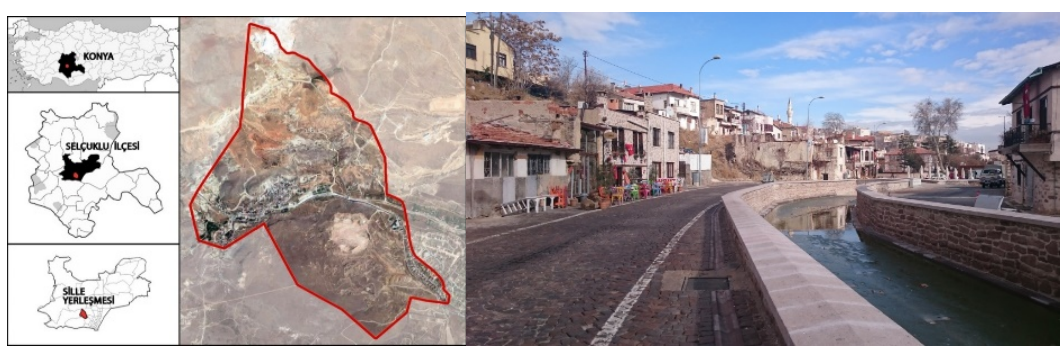

Figure 3. Location and general view of Sille (Sönmez et al., 2017)

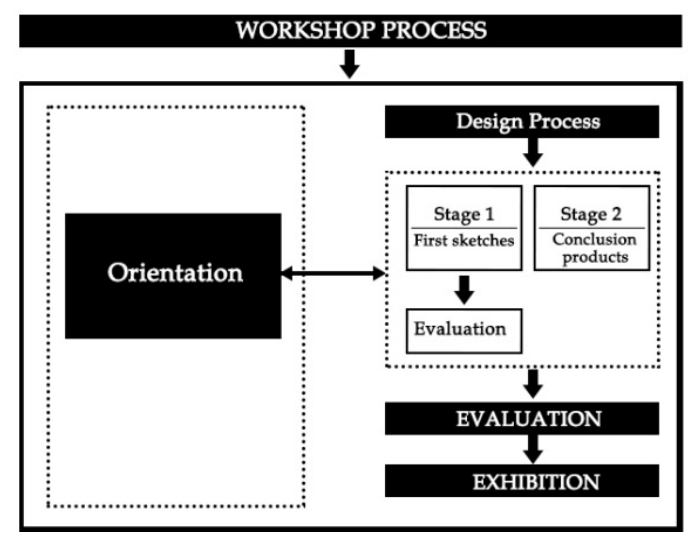

Figure 4. Study process

\section{HISTORY DESCRIBED WITH URBAN FURNITURE KONYA/SILLE WORKSHOP PROCESS 1}

The content of the "History Described with Urban Furniture Konya / Sille" themed workshop activity is to design urban furnishings, in the context of "Designing of Urban Furniture in Traditional Texture in Konya Sille within a Method and Creating e-Book" titled BAP01 project carried out by researchers, that are determined by Sille's needs with the participation of architects, interior designers and landscape architects undergraduate and graduate students. Sille is a settlement established in the Central Anatolian Region, within the borders of Selçuklu district in Konya. Sille, an important cultural tourism corridor in the province of Konya, is an important historical town with its historical and cultural background (Sönmez et al., 2017), (Figure 3).

It is inevitable that Sille would make a breakthrough as a branded tourist city when its historical structure is considered. In this context, the branding process for the city depends on the design process of the city furniture (Arpacioglu, 2017). Thus, the furniture design process in the workshop was planned as follows; orientation process, workshop process, evaluation process and the final of the workshop; creation of the model. The study process is summarized as follows (Figure 4).

\section{Orientation Process}

Initially, on November 23, 2016 and on November 30, 2016, orientation was conducted in Karadeniz Technical University, Faculty of Architecture Interior Architecture Department to determine the concepts of the participants. Concepts were discussed in the context of environment-function with various presentations in this process (Ertas et al., 2017) (Figure 5).

\footnotetext{
${ }^{1}$ This study was made by the help of the donnes within the scope of the Project title "Designing of Urban Furniture in Traditional Texture in Konya Sille within a Method and Creating e-Book" and coded KTÜ $535 \mathrm{O}$.
} 


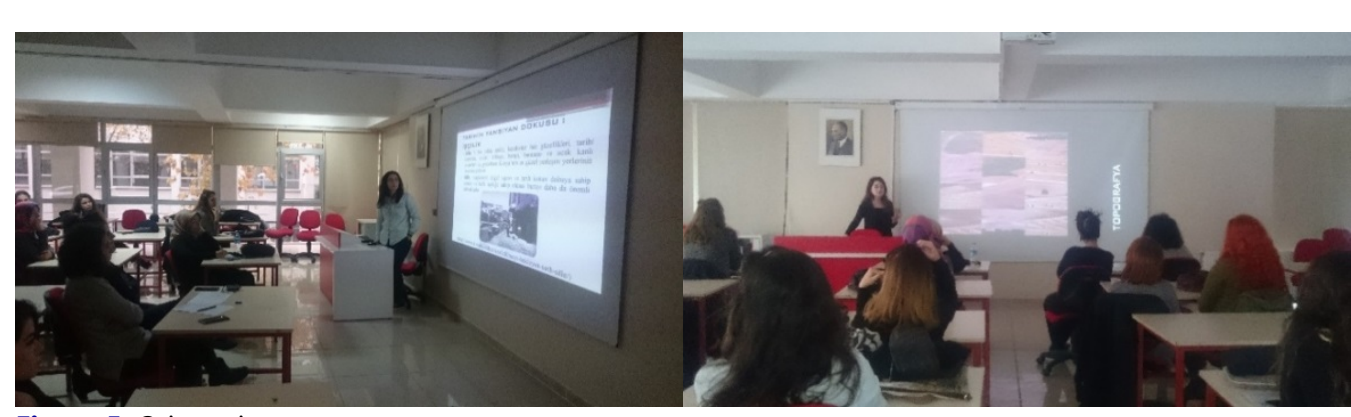

Figure 5. Orientation process

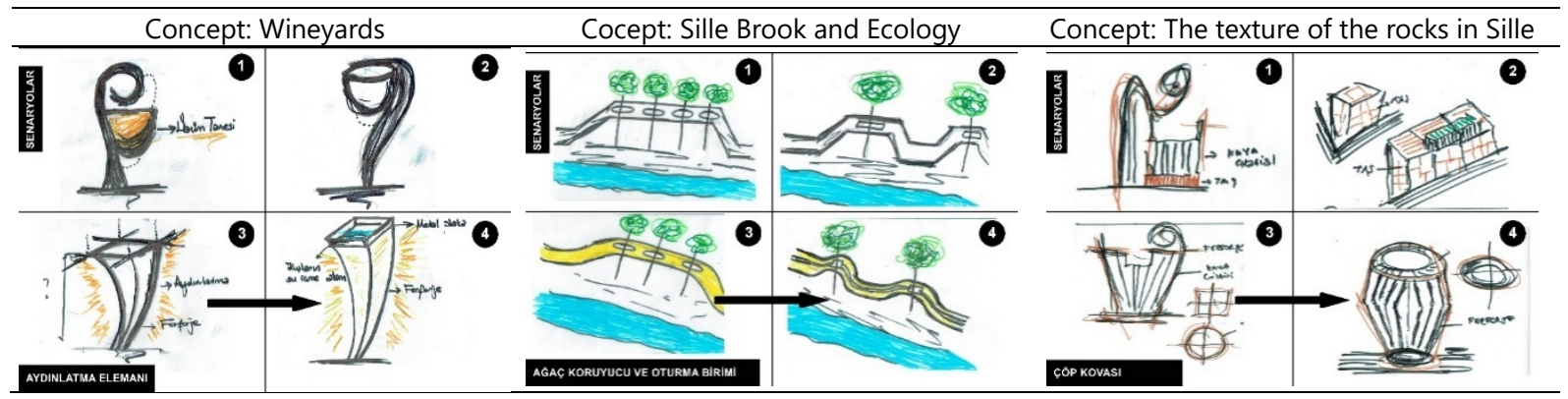

Figure 6. Concept and sketch
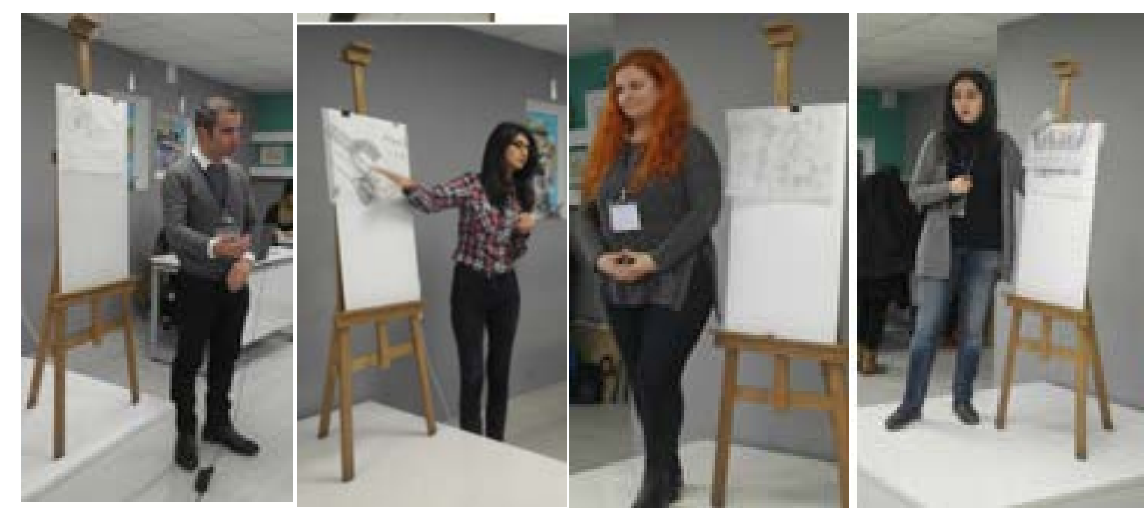

Figure 7. Verbal presentation of the designs
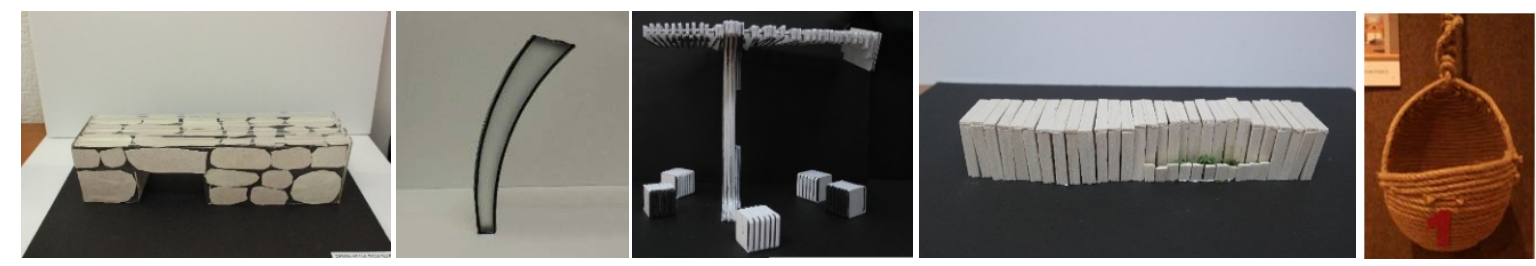

Figure 8. Models

\section{Design Process}

\section{Stage 1}

Information on urban furniture was provided to students to enable them to produce their initial ideas. On the first day of Workshop, the ideas were produced and the initial concept sketches were formed. Then, concept sketches were created based on the determined scenarios. On the final day, an assessment session was conducted with the practitioners and and participants (Figures 6, 7).

Later on, designs were finalized with the construction of models (Figure 8). Students and the practitioners documented their work in both workshops with videos. Later, these videos were edited to create a movie about the workshop process and the final designs (Figure 9) (Ertas et al., 2017). 


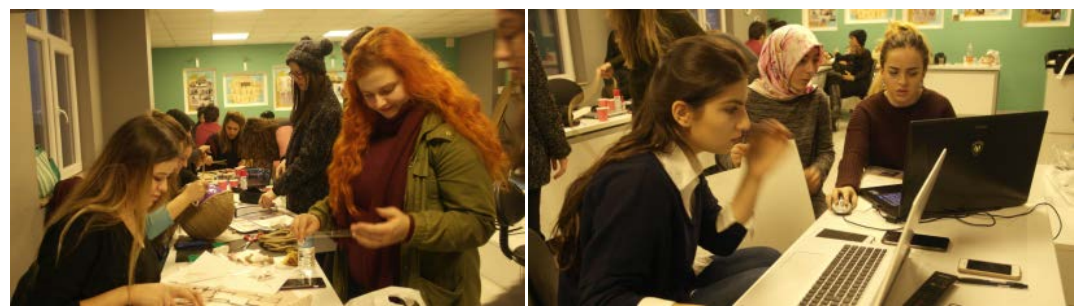

Figure 9. Making the video

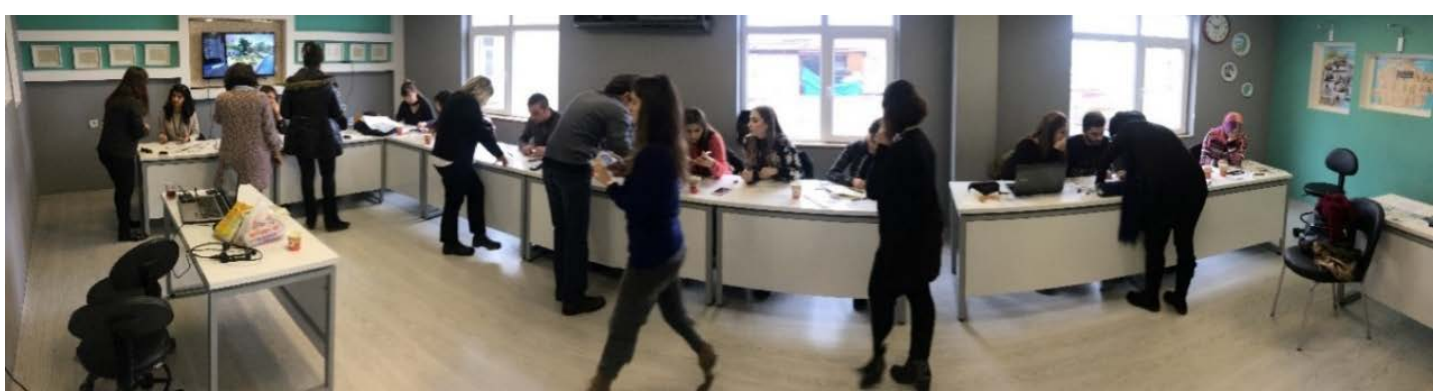

Figure 10. Workshop
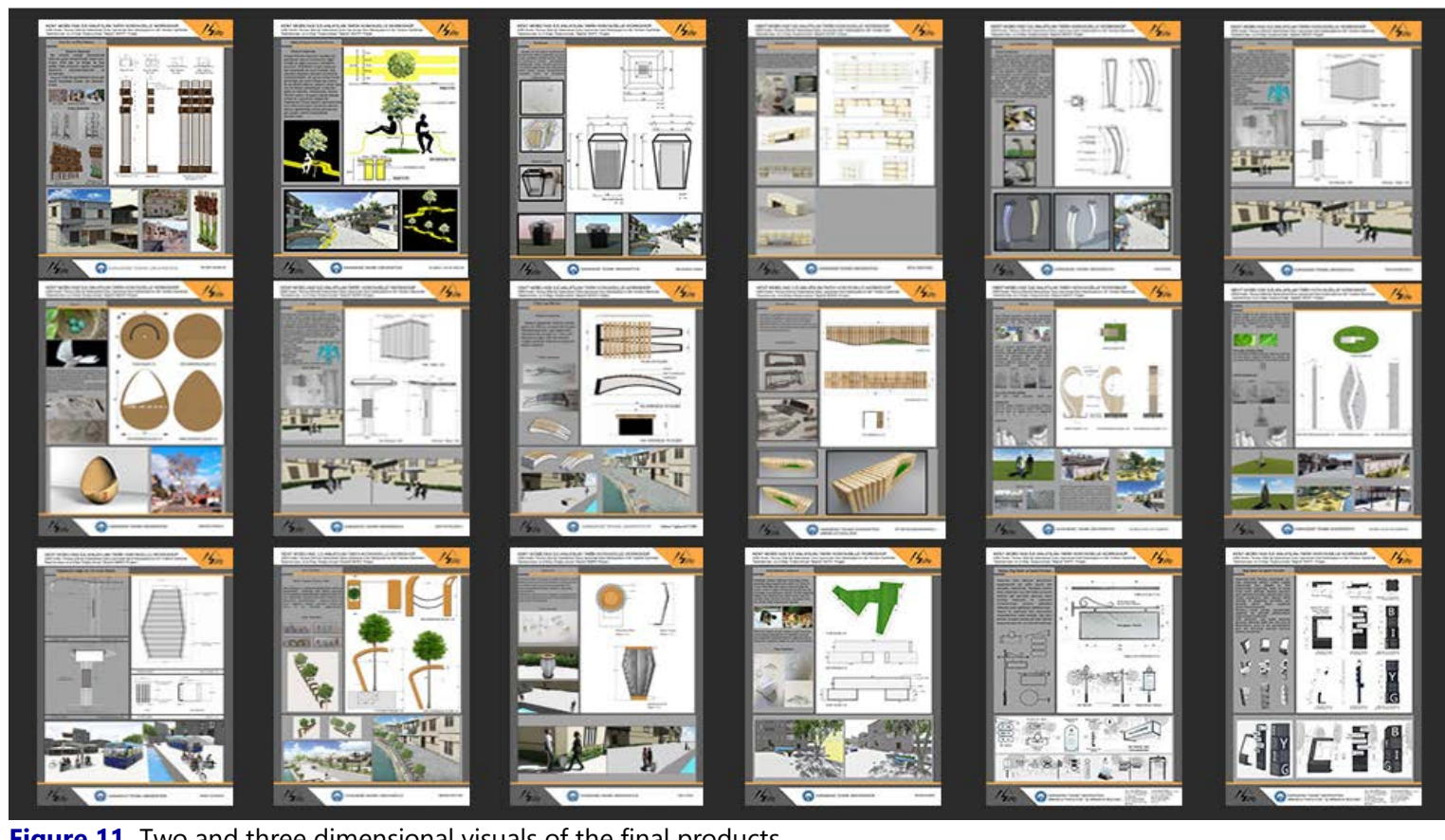

Figure 11. Two and three dimensional visuals of the final products

\section{Stage 2}

20 students were chosen for the workshop. However, in the final of the workshop, the products of 17 participants of 20 students were deemed suitable to be exhibited by deciding that they could team up with each other. With this activity, participants were expected to design urban furniture in interaction with each other in the workshop environment, and a common language was to be expected among the products designed for Sille (Figure 10).

As a result of the workshop activity, a model was prepared to transform one of the scenarios into a product depending on the concept. These designs were developed and prepared by each participant and their presentations were prepared. Developed 17 sheets of designs are shown below (Figure 11). 


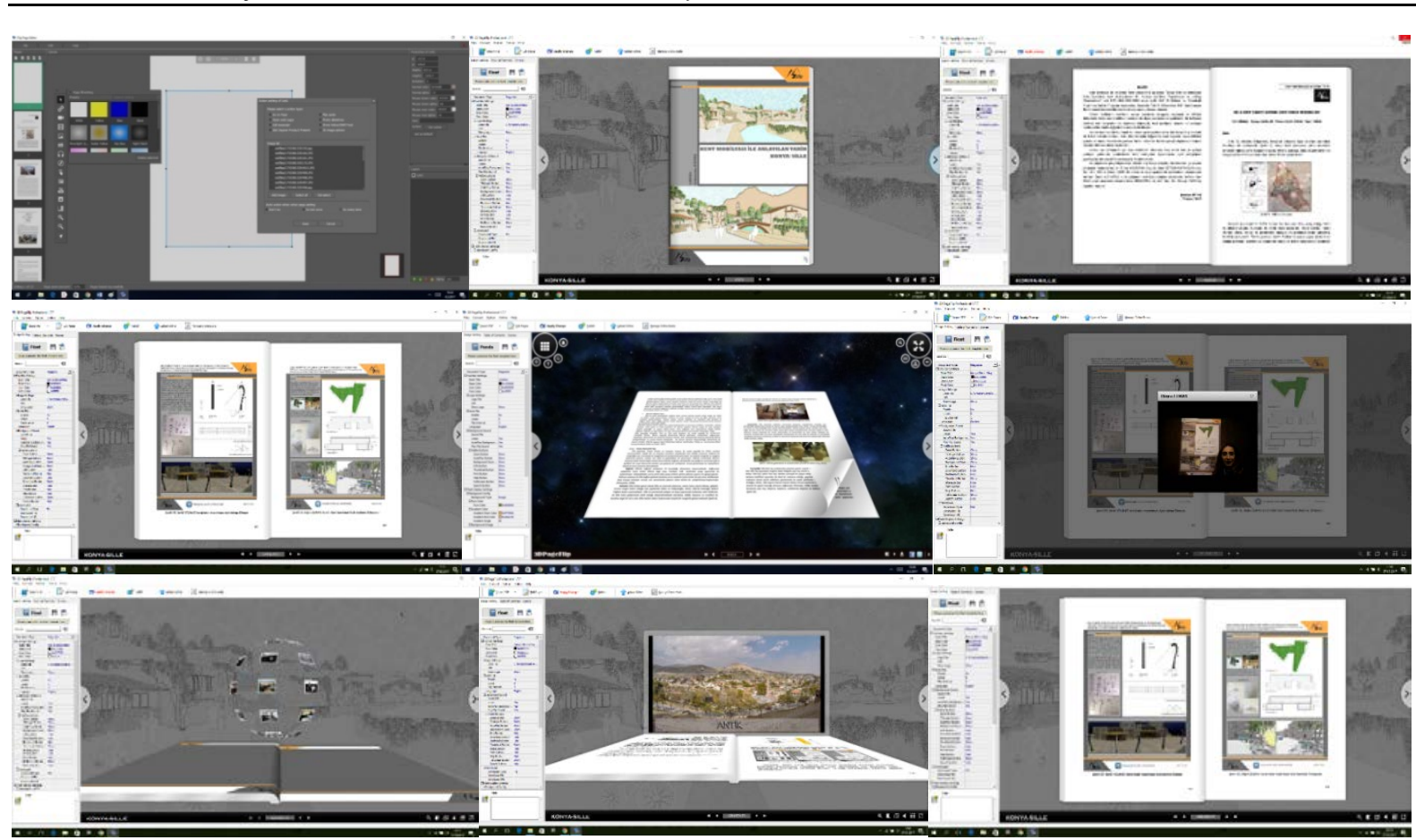

Figure 12. E-book study

The Bap project, which is completed with the workshop process, has revealed an important resource in this area as all the works are e-books. The e-book was prepared using the program '3DPageFlip Professional 1.7.7', and students who participated in this workshop contributed in the section where workshop is expressed (Figure 12).

In each step of the activity of the workshop carried out, technology has been used for different purposes. In this context, both research and presentation techniques and digital book preparation prepared within the scope of the project have strengthened the students' experience with the software they used.

\section{METHOD}

The aim of this research, which is carried out within the scope of "History Described with Urban Furniture Konya / Sille" themed workshop activity, is to reveal the opinions of students about the use of technology in workshop education which is an informal event. In this context, the contribution for formal education is discussed. The study carries a descriptive research feature in this aspect. The survey technique is used here to question the extent to which the students make use of the technology to express their designs during the workshop event. The criteria for measuring the technological achievements in this study were converted into questions and presented to the students. A total of 30 minutes of interviews were conducted with each person. Then, the results of these questions, which were evaluated by 20 students, were taken into consideration, taking into account the percentage (\%) value they received.

\section{Application Environment}

The research was first carried out on 3rd-4th December and secondly 17-18 December at Turkuaz Art House in Trabzon City Center with the Orientation studies at Karadeniz Technical University Faculty of Architecture Interior Design Department on 23rd November 2016 and 30th November 2016. Pre-study participants were selected based on their use of technology, mostly including senior and graduate students. It has been observed that only two students who are studying in the first and second classes are not at a sufficient level of computer use. In the interior architecture department there is the necessary technical equipment for presentations. And in the art house, students used their personal computers. All computers have an internet connection and all the necessary programs are installed on each computer during the operation. During the study, ArchiCAD, AutoCAD, 3DMax, Atlantis, Vray, power point and movie maker programs were installed on all computers. Those who wanted to use different programs during the study were also helped. 
Table 1. Participant Information in Workshop

\begin{tabular}{llll}
\hline SCHOOL & NAME-SURNAME & DEPARTMENT & EDUCATION LEVEL \\
\hline KTÜ & Melikenur SUBAŞI & Interior Architecture & 1st Grate \\
\hline A.Ü. & Hatice Tuğba AKTÜRK & Architecture & 2nd Grate \\
\hline KTÜ & Meryem ATMACA & Interior Architecture & 4th Grate (senior class) \\
\hline KTÜ & Ezgi AKÇA & Landscape Architecture & 4th Grate (senior class) \\
\hline KTÜ & Seda KAYIKÇIOĞLU & Landscape Architecture & 4th Grate (senior class) \\
\hline KTÜ & Büşra ELMAS & Landscape Architecture & 4th Grate (senior class) \\
\hline KTÜ & Betül İrem TEMIZ & Interior Architecture & 4th Grate (senior class) \\
\hline KTÜ & Kübra Nur YILDIZHAN & Interior Architecture & 4th Grate (senior class) \\
\hline KTÜ & Selver KOÇ & Interior Architecture & Postgraduate student \\
\hline KTÜ & Seyhan SEYHAN & Landscape Architecture & Postgraduate student \\
\hline KTÜ & Betül YILMAZ & Interior Architecture & Postgraduate student \\
\hline KTÜ & Elif SARAÇ & Landscape Architecture & Postgraduate student \\
\hline KTÜ & Merve BEZiRGAN & Landscape Architecture & Postgraduate student \\
\hline KTÜ & Zeynep Nilsun KONAKOĞLU & Interior Architecture & Postgraduate student \\
\hline KTÜ & Zeynep SADIKLAR & Interior Architecture & Postgraduate student \\
\hline KTÜ & Makbulenur BEKAR & Landscape Architecture & Postgraduate student \\
\hline KTÜ: Kadradent
\end{tabular}

KTÜ: Karadeniz Technical University, A.Ü.: Avrasya University

\section{Study Group}

After the banner for the workshop was designed and announced, student applications were received from the e-mail address given. The applicants were evaluated by the organizing committee and 20 students, mostly upper classes and graduate students, were selected for the workshop for technology use. However, in the final part of the workshop, the products of 16 participants of 20 students were seen to be suitable to be exhibited because they were seen enough both in technical terms and in terms of presentation (Table 1).

\section{RESULTS}

Within the scope of this study, the workshop, an informal activity, revealed student views on the use of technology in education. In this context, the contribution for formal education is discussed. The socio-demographic characteristics of the users in the questionnaire survey for these purposes were determined and the following results were obtained: $90 \%$ of the workshop participants are female and $10 \%$ are male. $95 \%$ of these participants are single, $5 \%$ are married. Of the participants, $85 \%$ are in the $20-25$ age group and $15 \%$ are in the $25-30$ age group. When the distribution according to occupations is examined, it is determined that $90 \%$ of the users are students and $10 \%$ of them are from officer groups. When the education levels of the participants were examined, it was found out that $55 \%$ of the participants were attending university education and $45 \%$ of them were continuing their graduate studies. The income situation of the participants is as follows; $60 \%$ have no income, $5 \%$ have $500-1000$, $15 \%$ have $1000-2000,20 \%$ have 3000 and above salaries. While $30 \%$ of the workshop participants were from different cities, $70 \%$ were from Trabzon (Table 2). 
Table 2. Socio-demographic status of participants

\begin{tabular}{|c|c|c|c|}
\hline Variables & & Frequency & Percentage \% \\
\hline \multirow{2}{*}{ Gender } & Male & 2 & 10 \\
\hline & Female & 18 & 90 \\
\hline & Total & 20 & 100.0 \\
\hline \multirow{6}{*}{ Age } & $15-20$ & - & - \\
\hline & $20-25$ & 17 & 85 \\
\hline & $25-300$ & 3 & 15 \\
\hline & $30-35$ & - & - \\
\hline & $35-40$ & - & - \\
\hline & $40+$ & - & - \\
\hline & Total & 20 & 100.0 \\
\hline \multirow{6}{*}{ Education } & Uneducated & - & - \\
\hline & Primary school & - & - \\
\hline & Secondary school & - & - \\
\hline & High school & - & - \\
\hline & Universty & 11 & 55 \\
\hline & Postgraduate & 9 & 45 \\
\hline & Total & 20 & 100.0 \\
\hline \multirow{5}{*}{ Grade } & 1st.grate & 1 & 5 \\
\hline & 2nd. grate & - & - \\
\hline & 3rd. grate & 1 & 5 \\
\hline & 4th.grate (senior class) & 8 & 40 \\
\hline & Postgraduate & 10 & 50 \\
\hline & Total & 20 & 100.0 \\
\hline \multirow{3}{*}{ Marital Status } & Married & 1 & 5 \\
\hline & Single & 19 & 95 \\
\hline & Total & 20 & 100.0 \\
\hline \multirow{6}{*}{ Job } & Unemployed & - & - \\
\hline & Student & 18 & 90 \\
\hline & Officer & 2 & 10 \\
\hline & Worker & - & - \\
\hline & Housewifer & - & - \\
\hline & Others & - & - \\
\hline & Total & 20 & 100 \\
\hline \multirow{5}{*}{ Income status } & No revenue & 12 & 60 \\
\hline & $500-1000$ & 1 & 5 \\
\hline & $1000-2000$ & 3 & 15 \\
\hline & $2000-3000$ & - & - \\
\hline & $3000+$ & 4 & 20 \\
\hline \multirow{3}{*}{ Homeland } & Total & 20 & 100.0 \\
\hline & Trabzon & 14 & 70 \\
\hline & Others & 6 & 30 \\
\hline & Total & 20 & 100.0 \\
\hline
\end{tabular}

During the workshop, students have acquired their own products using many programs. When we divide and build this process into visualization and video creation processed, it is seen that the students used AutoCAD and Photoshop in the visualization process (25\%),3Dmax (20\%), Lumion (15\%), ArchiCAD (10\%) and Skecthup (5\%) (Table 3). When asked which programs they used during the video preparation process; it has been deduced that $40 \%$ used Movie Maker, 30\% used Photoshop and Lumion programs (Table 4). When the participants asked why they chose these programs, the answers were as follows; being easy and having learned them during education process $(35 \%)$, being the program that can best explain the design and to get high-quality visual (20\%) (Table 5). It is foreseen that the students want to be able to put out a quality product in a short time because they prefer it because it is an easier program. Having learned these programs in particular during the training process has helped them throughout the workshop. 
Table 3. Technological programs participants use in the workshop process

\begin{tabular}{lcc}
\hline Variables & Frequency & Percentage \% \\
\hline AutoCad & $\mathbf{5}$ & $\mathbf{2 5}$ \\
\hline 3Dmax & 4 & 20 \\
\hline Lumion & 3 & 15 \\
\hline Maya & - & 0 \\
\hline Skecthup & 1 & 5 \\
\hline ArchiCAD & 2 & 10 \\
\hline Photoshop & $\mathbf{5}$ & $\mathbf{2 5}$ \\
\hline Total & 20 & 100.0 \\
\hline
\end{tabular}

Table 4. Programs used by participants during video preparation

\begin{tabular}{lcc}
\hline Variables & Frequency & Percentage \% \\
\hline Photoshop & 6 & 30 \\
\hline Lumion & 6 & 30 \\
\hline Movie Maker & $\mathbf{8}$ & $\mathbf{4 0}$ \\
\hline Total & 20 & 100,0 \\
\hline
\end{tabular}

Table 5. Reasons for participants to choose these programs

\begin{tabular}{lcc}
\hline Variables & Frequency & Percentage $\%$ \\
\hline Being easy & $\mathbf{5}$ & $\mathbf{3 5}$ \\
\hline Being the program that can best explain the design & 4 & 20 \\
\hline Having learned it during educational process & $\mathbf{7}$ & $\mathbf{3 5}$ \\
\hline To get high-quality visual & 4 & 20 \\
\hline Total & 20 & 100,0 \\
\hline
\end{tabular}

Table 6. Contribution levels of participants to the preparation of the book digitally

\begin{tabular}{lcc}
\hline Variables & Frequency & Percentage \% \\
\hline Making a video & $\mathbf{1}$ & 5 \\
\hline Prepare 3D images & $\mathbf{8}$ & $\mathbf{4 0}$ \\
\hline Making 2D drawings & 7 & 35 \\
\hline Sketching & $\mathbf{5}$ & 15 \\
\hline Doing research & $\mathbf{2}$ & 10 \\
\hline Toptal & 20 & 100.0 \\
\hline
\end{tabular}

Table 7. Participants' thoughts on the e-book being accessible to everyone

\begin{tabular}{lcc}
\hline Variables & Frequency & Percentage \% \\
\hline Permanence of our work & $\mathbf{8}$ & $\mathbf{4 0}$ \\
\hline Easily accessible at any time & 6 & 30 \\
\hline Setting an example for other studies & 4 & 20 \\
\hline Giving information about intervention in historical cities & 2 & 10 \\
\hline Total & $\mathbf{2 0}$ & $\mathbf{1 0 0 . 0}$ \\
\hline
\end{tabular}

Workshop participants contributed to the work in many stages. When we question the contribution levels of the e-book in digital form, which is one of the biggest goals of the workshop, preparing 3D images (40\%) and making 2D drawings (35\%) are the highest results. Other answers are $(15 \%)$ sketching, $(10 \%)$ doing research and (5\%) making a video (Table 6).

As a result of the surveys done, all of the workshop participants' opinions were evaluated on the idea that ebooks of their works could be created and accessed online. The answers given by the participants were collected in 4 categorized groups. While $40 \%$ of the participants think that it is useful that every detail they make within the workshop is permanent on the internet environment, $30 \%$ stated that it is important to have an easy access to them, $20 \%$ to be an example and $2 \%$ to shed light on future work on interventions to be made to a historical city were among the received results (Table 7).

When we question the yield of technological programs that participants use in the workshop process, the following are among the answers received; I could develop the design in a shorter time (30\%), I learned the features I did not know about the programs (25\%), I could express my thoughts in different ways (20\%), I could express my original concept $(10 \%)$, it helped me create original designs $(10 \%)$, I could reflect my aesthetic concerns better $(5 \%)$ (Table 8). 
Table 8. Levels of yield of the technological programs used by the participants in the workshop process

\begin{tabular}{lcc}
\hline Variables & Frequency & Percentage \% \\
\hline I learned about features that I do not know about programs & 5 & 25 \\
\hline I was able to create my design in a shorter time & $\mathbf{6}$ & $\mathbf{3 0}$ \\
\hline I could express my thoughts in different ways & 4 & 20 \\
\hline The original designs made it easy to create & 2 & 10 \\
\hline I could express my original concept & 2 & 10 \\
\hline I could reflect my aesthetic concerns better & 1 & 5 \\
\hline Total & $\mathbf{2 0}$ & $\mathbf{1 0 0 . 0}$ \\
\hline
\end{tabular}

Table 9. Steps that participants use 2 and 3 dimensional programs in the workshop process

\begin{tabular}{lcc}
\hline Variables & Frequency & Percentage $\%$ \\
\hline In the design process & $\mathbf{3}$ & 15 \\
\hline In sketch work & $\mathbf{1}$ & 5 \\
\hline In sheet preparation phase & $\mathbf{8}$ & $\mathbf{4 0}$ \\
\hline In video preparation phase & $\mathbf{7}$ & 35 \\
\hline In book formation phase & $\mathbf{1}$ & 5 \\
\hline Total & $\mathbf{2 0}$ & $\mathbf{1 0 0 . 0}$ \\
\hline
\end{tabular}

Table 10. Assessment of participants' adaptation of technology and workshop in workshop process

\begin{tabular}{lcc}
\hline Variables & Frequency & Percentage \% \\
\hline Motivated during the workshop phase through technological programs & $\mathbf{6}$ & $\mathbf{3 0}$ \\
\hline Created environments to learn new programs & 2 & 10 \\
\hline Provided a chance to revise and redo through technological programs & 3 & 15 \\
\hline Made it possible to get faster product through technological programs & 4 & 20 \\
\hline Provided me with more tending to 3D technological programs & 2 & 10 \\
\hline Enabled us to interact with technological program usage & 3 & 15 \\
\hline Total & $\mathbf{2 0}$ & $\mathbf{1 0 0 . 0}$ \\
\hline
\end{tabular}

Technological programs are very useful for students because they have to create their designs within a certain period of time in their workshop work. Technological programs are quite useful for tracking current programs and for drawing short-term ideas. Throughout this process, students have benefited from technological programs in every step. It has been concluded that the students used these programs, which we can categorize as 2 dimensional and 3 dimensional programs, mostly $(40 \%)$ in sheet preparation phase, followed by (35\%) video preparation phase, $(15 \%)$ design phase, $(5 \%)$ sketch and book forming phases (Table 9). It is envisaged that the exhibition work, which is one of the biggest gains of the workshop, affects these rates.

Technological programs are an integral part of architectural education. There are many benefits such as expressing ideas to the other side and making abstract products concrete. All these programs accompanied the participants during the workshop. Participants were asked to evaluate the technology and workshop harmonization in this process and the answers are stated in Table 10. Among the answers received (30\%) were motivated in the workshop phase through workshop technological programs, $(20 \%)$ made it possible to export products faster through technological programs, $(15 \%)$ had the chance to revise and redo through technological programs and were enabled to interact with the use of technological programs, $(10 \%)$ were able to learn new programs according to Table 10. It is foreseen that among the reasons for the fact that the rates of rapid product creation, revising and redoing, and quality product removal answers are close to each other among the answers, there is also quality and aesthetic concerns at the same time while students want to produce fast products.

Workshop is a team work. Many participants that came together for the same purpose have a single objective. Many studies, such as workshop in the participants' training process, can help guide group work and create a team spirit. When we question the level of use of technology in leading to group work in the workshop process, the replies were as follows; (55\%) leads, (25\%) definitely leads, (15\%) disagree, (5\%) no idea (Table 11). The reasons for giving these answers were briefly explained and the answers received were categorized in 4 groups. These answers were as follows: (45\%) increased sharing, information exchange, (30\%) we could express our design better, (15\%) helped create a better quality product and $(10 \%)$ helped create a better quality product in a short time (Table 11). These results are related to the finding of "design studios are both learning centers and are associated with a social organization like other learning environments" as Deasy and Laswell pointed out in 1985's work (Deasy and Laswell, taken from 1985) (Demirbaş and Demirkan. 2003, p. 438). 
Table 11. Levels of participants' use of technology in group workshops during the workshop process

\begin{tabular}{lcc}
\hline Variables & Frequency & Percentage $\%$ \\
\hline Definitely leads & 5 & 25 \\
\hline Leads & $\mathbf{1 1}$ & $\mathbf{5 5}$ \\
\hline No idea & 1 & 5 \\
\hline Disagree & 3 & 15 \\
\hline Strongly disagree & - & 0 \\
\hline Total & $\mathbf{2 0}$ & $\mathbf{1 0 0 . 0}$ \\
\hline Could you briefly explain why? & Frequency & Percentage \% \\
\hline Variables & 6 & 30 \\
\hline We could express our design better & $\mathbf{9}$ & $\mathbf{4 5}$ \\
\hline Increased sharing, information exchange, & 3 & 15 \\
\hline We could express our design better & 2 & 10 \\
\hline Helped create a better quality product in a short time & $\mathbf{2 0}$ & $\mathbf{1 0 0 . 0}$ \\
\hline Total & &
\end{tabular}

Table 12. Participants' contribution levels of internet use during workshop

\begin{tabular}{lcc}
\hline Variables & Frequency & Percentage \% \\
\hline Yes & $\mathbf{1 9}$ & $\mathbf{9 5}$ \\
\hline No idea & - & 0 \\
\hline No & 1 & 5 \\
\hline Total & $\mathbf{2 0}$ & $\mathbf{1 0 0 . 0}$ \\
\hline
\end{tabular}

Table 13. In which phases participants used internet for the workshop

\begin{tabular}{lcc}
\hline Variables & Frequency & Percentage \% \\
\hline Design phase & 5 & 25 \\
\hline Sketch phase & 1 & 5 \\
\hline Sheet preparation phase & $\mathbf{7}$ & $\mathbf{3 5}$ \\
\hline Video preparation phase & 6 & 30 \\
\hline E-book formation & 1 & 5 \\
\hline \multicolumn{1}{c}{ Total } & $\mathbf{2 0}$ & $\mathbf{1 0 0 . 0}$ \\
\hline
\end{tabular}

Table 14. Contribution levels of participants to the formal education of workshop

\begin{tabular}{lcc}
\hline Variables & Frequency & Percentage $\%$ \\
\hline Yes, it was helpful & $\mathbf{1 8}$ & $\mathbf{9 0}$ \\
\hline No idea & - & 0 \\
\hline No it was not helpful & 2 & 10 \\
\hline Total & $\mathbf{2 0}$ & $\mathbf{1 0 0 . 0}$ \\
\hline
\end{tabular}

Table 15. At what stage participants use formal education

\begin{tabular}{lcc}
\hline Variables & Frequency & Percentage $\%$ \\
\hline In sheet (presentation) presentation phase & $\mathbf{7}$ & $\mathbf{3 5}$ \\
\hline In oral presentation phase & $\mathbf{7}$ & $\mathbf{3 5}$ \\
\hline In research phase & 6 & 30 \\
\hline Total & $\mathbf{2 0}$ & $\mathbf{1 0 0 . 0}$ \\
\hline
\end{tabular}

At almost all stages of the workshop, internet usage has been observed. According to Table 12, when we asked the participants whether the workshop was helpful, (95\%) replied yes, it was and (5\%) replied no, it wasn't. When it was questioned which phases this use occurred, it was concluded that $35 \%$ in sheet preparation phase, $30 \%$ in video preparation phase, $25 \%$ design phase, $5 \%$ e-book formation and sketch phase (Table 13).

The use of technology in the workshop process was aimed, and the formal training contribution of the techniques used by the participants in the course of the process management was also questioned.

In Table 14, when we asked whether this process has been helpful (90\%) replied "yes, it was helpful", and (10\%) replied "no, it was not helpful" (Table 14). When it was questioned which phases this process contributed to, (35\%) stated that it contributed to sheet (presentation) preparation phase, (35\%) oral presentation phase and (30\%) research phase (Table 15). 


\section{DISCUSSION AND CONCLUSION}

Today, the use of technology is dominant in the field of education as it is in every field. Architectural design education is also influenced by these developments. Traditional architectural design education takes place in the form of technical drawings and model work on paper with one-on-one talks between the instructor and the student.

With the use of technology in architectural design education, students can work with two-dimensional drawings, three-dimensional models, and use computer-aided tools and simulation environments. Because visual expression comes out with the visual thinking in design phase. Visual narratives are the process of being able to explain the data formed in the mind together with the process of visual thinking. In addition to this, interactive interaction process of architectural education can be supported by distance education on internet. The integration of architectural design and technology in terms of the students can be achieved by establishing the most suitable connection and bringing it in the studio environment.

In this study, which aims to determine the technologlcal achievement and its interaction with formal education with the "History Described with Urban Furniture Konya / Sille" themed workshop carried out in the scope of BAP 01 project SBA-2016-5350 at Karadeniz Technical University in the 2016-2017 academic year, the results of the questionnaire on the use of heat technology in informal activity of the students were evaluated.

As a result, it was observed that students found the use of technology favorable during the workshop and preferred it in the education process. According to the results of the study, it is determined that students use AutoCAD when making drawings, and they use movie maker program when making videos because they are both easy to learn and also taught in education process. Participants have commented on the idea of creating the design in a shorter time, especially with 2D drawings and 3D visualizations. In this study, it is stated that students' use of technology led to group work and increase sharing and exchange information. Furthermore, it is stated for the programs that are used and for the internet usage that they are preferred for short term activities such as workshops and that they increase motivation in the preparation of sheet design (presentation) which produces final products. In addition, digital book work, which is the continuation of this work, has also been found to be interesting because of its technology-based nature and permanent and easy accessibility. It was also supported by the survey results that all studies contributed to each phase of the formal education process.

The technological tools used in these short and long informal events contribute to the students to find solutions to the problems more quickly. In addition, in these environments, student groups of different classes interact with each other and share their experience with the use of technological tools. Besides, as the technological tools used by each discipline change in these studies, in which different disciplines coexist, students are experimenting with new techniques or new techniques for accessing information. All of this is happening shortly in the context of informal activity, but it provides an important accumulation of knowledge for formal education.

The study findings were supported by the results of the studies conducted by Pacey 2003; Çivici, Bacanak 2003; Yildırım, 2011; Zor, 2006, Korkut, 2016, Uğur and Özgür 2003; Van den Akker, 2006. Design studios are environments that integrate skills with different types of expertise. It is useful for students who face a wide variety of subjects that an architect has to deal with and need to tackle different topics. In this context, we must not forget that technology functions as a design generator (Lökke, 2002, Van den Akker, 2006). Because use of technology not only affected several fields, but also utilized in architectural design education. Use of technology was adopted for a number of reasons, including behavioral intent, tendency for use, and perception of ease of use (Pacey, 2003; Chivi, Bacanak, 2003). Today, this interaction introduced changes in the preparation and presentation of art, design, planning and presentation techniques (Y1ldirım, 2011; Korkut, 2001; Zor, 2006). These software are preferred because of their advantages such as saving time, low costs, simplicity of revision, easy storage of data, opportunity to draw without errors, duplication of drawings at fast speed and facile generation of new alternatives (Uğur and Özgür, 2003, cited by Korkut, 2016).

The present study differs from previous studies in terms of the inclusion of student views and conclusions on the relationship between architectural education and technology based on the study findings and the assessment of the contribution of informal activities to formal activities.

\section{RECOMMENDATIONS}

In this context, the following suggestions can be made in order to increase the usage of technology for these and similar studies and diversify in different ways. These proposals have been put forward in the name of providing contribution to the use of technological tools for students in today's conditions by transforming informal activities into more efficient operations.

1. In such events, giving information about the programs in order to bring the design education and technology synergy to the students, showing examples of how they will be used in which stage, 
2. Contributing to the learning of different types of technological tools by providing group studies from different classes and disciplines,

3. Instructors having knowledge of different technological tools in informal events and guidance for the use of technology by the learner in obtaining information or final product,

4. Giving information about the new technological programs that can be used in education and professional life

5. Contributing to the program which could be the best for the original product to be designed or the solution to be developed,

6. The new generation student profile's keeping pace with the requirements and changing of the time and emphasizing the importance of technological tools in reaching the competence level,

7. Contribution of technological programs to speed while achieving concrete product,

8. Emphasizing those technological programs, visual presentations and professional field work enable the increase of quality,

9. In such events, there should be group projects that the student is actively involved in, doing researches, exchanging ideas with each other, sharing responsibility and presenting group projects; students should be expected to demonstrate perceptual, interpretive and analytical skills through technological programs.

As a result, this study has shown that the students use the technology at every stage of their work in the workshop process which is realized with the participation of students from architecture, interior architecture and landscape architecture departments that include design education. In addition to formal education, the use of technology in the workshop training process, which is one of the informal educational activities, is very necessary for the students to develop themselves as well as being useful for them.

\section{REFERENCES}

Armstrong, H. (1999), Design Studios as Research: an Emerging Paradigm for Landscape Architecture. Landscape Review, 2, 5-25.

Arpacıoğlu, Ü., Kasap., M., \& Durukan., A. (2017). Anadolu Geleneksel Mimarimiz ve Geleceğe Taşınan Kimlik "Sille" (Anatolian Traditional Architecture and transported to the future Identity "Sille"). In Ş. Ertaş (Eds)., Kent Mobilyast ile Anlatılan Tarih Konya/Sille (Historically Narrated with Urban Furniture, Konya / Sille). Ankara: Detay Publication.

Bacanak, A., Karamustafaoğlu, O., \& Köse S. (2003). A New View: Technology Literacy in Education. Pamukkale University Journal of Education, 14(14), 191-196.

Barth, F., Bologna, R., Dizenzo, A., \& Massaccesi, C. (2012). Teaching and Learning Technology of Architecture Experiences in the Moodle Platform. 4th International Conference on Education and New Learning Technologies (EDULEARN), Barcelona, Spain, 735-743.

Casakin, H., \& Goldschmidt, G. (1999). Expertise and the Use of Visual Analogy: Implications for Design Education. Faculty of Architecture and Town Planning, 20, 153-175.

Ciravoğlu, A. (2001). On The Workshop - Studio Coherence in the Architectural Design Education (Masters Thesis). Istanbul: Istanbul Technical University, Institute of Science and Technology.

Çivici, T., \& Kale, S. (2007). Mimari Tasarım Bürolarında Bilişim Teknolojilerinin Kullanımını Etkileyen Faktörler: Bir Yapisal Denklem Modeli (Factors That Influence Acceptance of Information Technologies in Architectural Design Firms: a Structural Equation Model), İnşaat Yönetimi of the Congress Proceedings, 119128.

Demirbaş O. O., \& Demirkan, H. (2007), Learning styles of design students and the relationship of academic performance and gender in design education. Learning and Instruction, 17, 345-359.

Ertaş, S.. (2017). “Designing of Urban Furniture in Traditional Texture in Konya Sille within a Method and Creating e-Book", coded KTÜ 535O, project manager: Ertaş, Ş.

Ertaş, Ş., Kurak Açıcı, F., Demire, Ö., Özdemir, İ., Kurdoğlu, B., Arpacıoğlu, Ü., .. , \& Bekar, M. (2017). Kent Mobilyası ile Anlatılan Tarih Konya Sille Etkinlikleri: Tasarım Yarışmaları-Workshop-Sergi (Historically Narrated with Urban Furniture, Konya / Sille Activities: Design Competitions-Workshop-Exhibition). In Ş. Ertaş (Eds)., Kent Mobilyası ile Anlatılan Tarih Konya/Sille (History Narrated with Urban Furniture, Konya/Sille). Ankara: Detay Publication.

Keçel, N. (2009). Technical Analyze Of Design and Technology Facilities and Designing Model Workshop (Masters Thesis). Ankara: Gazi University Institute Of Science And Technology. 
Korkut, A., \& Özyavuz, M. (2016). A Research on The Necessity of Technology Infrastructure in Design Training, Journal of Tekirdag Agricultural Faculty, 13(2).

Kvan, T., \& Yunyan, J. (2005), Students' Learning Styles and Their Correlation with Performance in Architectural Design Studio. Design Studies, 26, 19-34.

Lökçe, S. (2002). Integrating Technology into the Architectural Curriculum. Journal of the Faculty of Engineering and Architecture of Gazi University, 17(3).

Nerdinger, W. (2004). Dinner for Architects. New York, NY: W. W. Norton \& Company, Inc. 21.

Pacey, A. (1983). The Culture of Technology. Cambridge: The M.I.T. Press.

Sönmez, E., Sadıklar, Z., Kulak, F., \& Torun, A. (2017). Sille Kent Tarihi Aksının Kent Kimlik Bileşenleri. In Ş. Ertaş (Eds)., Kent Mobilyası ile Anlatılan Tarih Konya/Sille (History Narrated with Urban Furniture, Konya / Sille). Ankara: Detay Publication.

Uğur, A., \& Özgür, E. (2003). Internet Üzerinde Üç Boyut ve Mimarlıkta Web 3D (Three Dimensional Graphics on the Internet and Web3D in Architecture). IX. Internet Conference in Turkey (INET-TR 2003), İstanbul, 24-30.

Van den Akker, J., Gravemeijer, K., McKenney, S., \& Nieveen, N. (Eds.). (2006). Educational Design Research. UK: Routledge.

Yıldırım, T., İnan, N., \& Yavuz, A. Ö. (2010). Effects and Utilization of Information Technologies in Architectural Design Education. Academic Information Conference, Muğla.

Yıldırım, T., Özen Yavuz, A., \& İnan, N. (2011). Comparison of Traditional and Digital Visualization Technologies in Architectural Design Education, International Journal of Informatics Technologies, 3(3), 17-26.

Zor, A. (2006). Görsel Sanatlar Dersinde Bilgisayar Kullanımının Gerekliliği (The Necessity of Computer Usage in the Visual Arts Lessons). A. U. Journal of Bayburt Education, 1(1), 111-119.

\section{http://www.ejmste.com}

